\title{
PERBEDAAN ANTARA EFEK PEMBERIAN VITAMIN C DAN VITAMIN E TERHADAP KUALITAS SPERMATOZOA TIKUS WISTAR (RATTUS NORVEGICUS) JANTAN SETELAH DIBERI PAPARAN ASAP ROKOK
}

\author{
${ }^{1}$ Astrid Giovani Sitohang \\ ${ }^{2}$ Benny Wantouw \\ ${ }^{2}$ Edwin de Queljoe
}

\author{
${ }^{1}$ Kandidat Skripsi Fakultas Kedokteran Universitas Sam Ratulangi Manado \\ ${ }^{2}$ Bagian Biologi Fakultas Kedokteran Universitas Sam Ratulangi Manado \\ Email: astrid@sitohang.org
}

\begin{abstract}
Gaseous components of cigarette smoke have a potential to generate free radicals that can damage sperm. Vitamin $C$ is water soluble and vitamin $E$ is a fat-soluble antioxidant that is effective in dealing with free radicals. The aim of this research was to look at the differences between the effects of vitamin $C$ and vitamin $E$ on spermatozoa quality of male wistar rats (Rattus norvegicus) after exposure to cigarette smoke. Methods: This research used a completely randomized experimental design. The sample of the research were 15 male wistar rats which were randomly divided into 3 groups, i.e. group $\mathrm{P}_{0}$ was given exposure to smoke from 2 bars of cigarette without giving vitamin $C$ and vitamin $E$, group $\mathrm{P}_{1}$ was given exposure to smoke from 2 bars of cigarette and vitamin C 1,8 $\mathrm{mg}$ / day and group $\mathrm{P}_{2}$ was given exposure to smoke from 2 bars of cigarette and vitamin E 1,44 mg / day. The treatment was given for 52 days. Results: The results of this research showed an increasing spermatozoa quality of group $\mathrm{P}_{1}$ and $\mathrm{P}_{2}$ compared with the group $\mathrm{P}_{0}$. The mean concentration of spermatozoa obtained on group $\mathrm{P}_{1}\left(78,78 \times 10^{6} / \mathrm{ml}\right)$ and group $\mathrm{P}_{2}\left(123,13 \times 10^{6} / \mathrm{ml}\right)$. The mean motility of spermatozoa obtained on group $\mathrm{P}_{1}(72,00 \%)$ and group $\mathrm{P}_{2}(80,25 \%)$. The mean of normal morphology of spermatozoa obtained on group $\mathrm{P}_{1}(67,63 \%)$ and group $\mathrm{P}_{2}(74,00 \%)$. Conclusion: The conclusion from this research showed that there is a difference between spermatozoa quality of group treated with vitamin $C$ and vitamin $E$ after exposure to cigarette smoke, with vitamin $\mathrm{E}$ had an higher average on spermatozoa quality.
\end{abstract}

Keywords: cigarette smoke, vitamin C, vitamin E, the quality of spermatozoa

\begin{abstract}
Abstrak: Latar Belakang: Komponen gas dari asap rokok berpotensi untuk menimbulkan radikal bebas yang dapat merusak spermatozoa. Vitamin $\mathrm{C}$ yang larut dalam air dan vitamin $\mathrm{E}$ yang larut dalam lemak merupakan antioksidan yang efektif dalam mengatasi radikal bebas. Tujuan penelitian ini adalah untuk melihat perbedaan efek antara pemberian vitamin C dan vitamin E terhadap kualitas spermatozoa tikus wistar (Rattus norvegicus) jantan setelah diberi paparan asap rokok. Metode: Penelitian ini menggunakan metode penelitian eksperimental dengan menggunakan rancangan acak lengkap. Sampel yang digunakan adalah 15 tikus wistar jantan yang dibagi secara acak menjadi 3 kelompok yaitu kelompok $\mathrm{P}_{0}$ yang mendapat perlakuan paparan asap rokok 2 batang tanpa pemberian vitamin $C$ dan vitamin $E$, kelompok $\mathrm{P}_{1}$ dengan perlakuan pemaparan asap rokok 2 batang dan vitamin C 1,8 mg/hari dan kelompok $\mathrm{P}_{2}$ dengan perlakuan pemaparan asap rokok 2 batang dan vitamin E 1,44 mg/hari. Perlakuan diberikan selama 52 hari. Hasil: Hasil penelitian menunjukkan adanya peningkatan kualitas spermatozoa kelompok $\mathrm{P}_{1}$ dan $\mathrm{P}_{2}$ dibandingkan dengan kelompok $\mathrm{P}_{0}$. Rata-rata konsentrasi spermatozoa kelompok $\mathrm{P}_{1}$ didapatkan $\left(78,78 \times 10^{6} / \mathrm{ml}\right)$ dan kelompok $\mathrm{P}_{2}\left(123,13 \times 10^{6} / \mathrm{ml}\right)$. Rata-rata motilitas spermatozoa kelompok $\mathrm{P}_{1}(72,00 \%)$ dan kelompok $\mathrm{P}_{2}(80,25 \%)$. Rata-rata
\end{abstract}


morfologi normal spermatozoa kelompok $\mathrm{P}_{1}(67,63 \%)$ dan kelompok $\mathrm{P}_{2}(74,00 \%)$. Simpulan: Kesimpulan dari penelitian ini didapatkan bahwa terjadi perbedaan kualitas spermatozoa antara pemberian vitamin $\mathrm{C}$ dan vitamin $\mathrm{E}$ setelah pemaparan asap rokok, dengan vitamin $\mathrm{E}$ memiliki rata-rata kualitas spermatozoa lebih tinggi.

Kata kunci: asap rokok, vitamin C, vitamin E, kualitas spermatozoa

Rokok mengandung lebih dari 4000 bahan kimia dan sekitar 200 diantaranya berbahaya bagi kesehatan. ${ }^{1}$ Asap rokok merupakan campuran kompleks yang mengandung banyak senyawa. Lebih dari seribu unsur utama dari asap rokok telah diidentifikasi, termasuk nikotin, fenol, asetaldehida, dan kadmium. ${ }^{2}$ Beberapa komponen asap rokok merupakan gas, seperti karbon monoksida (CO), karbon dioksida $\left(\mathrm{CO}_{2}\right)$, hidrogen sianida $(\mathrm{HCN})$, dan nitrogen oksida $\left(\mathrm{NO}_{\mathrm{x}}\right)$ yang sangat berpotensi untuk menimbulkan radikal bebas. Beberapa komponen asap rokok lain merupakan partikel padat, seperti nikotin, fenol, tar dan kadmium.,

Menurut WHO tahun 2008, Indonesia menduduki peringkat ke-3 dengan jumlah perokok terbesar di dunia dan peringkat ke5 untuk konsumen rokok terbesar tahun 2007. Prevalensi perokok di Indonesia tahun 2010 menurut Riset Kesehatan Dasar Nasional sebesar 34,7\%. Provinsi dengan prevalensi perokok tertinggi ditempati oleh Kalimantan Tengah dengan persentase sebesar 43,2\%, sedangkan Sulawesi Tenggara memiliki prevalensi perokok terendah sebesar 28,3\%. Sulawesi Utara menempati peringkat ke-18 dengan prevalensi sebesar $36,2 \%{ }^{5}$

Rokok dapat menyebabkan terjadinya stres oksidatif yang mengakibatkan kualitas spermatozoa menurun. ${ }^{6}$ Hal tersebut terjadi melalui peningkatan kadar Reactive Oxygen Species (ROS) dan penurunan antioksidan semen yang mengganggu spermatogenesis. $^{4,6,7}$ Radikal bebas yang ditimbulkan asap rokok dapat menyebabkan kerusakan deoxyribonucleic acid (DNA) dan apoptosis sel spermatozoa. ${ }^{4}$

Para ahli mengatakan bahwa radikal bebas dapat dikendalikan dan dicegah oleh antioksidan. Salah satu antioksidan ialah vitamin E (tocopherol) yang merupakan vitamin yang larut dalam lemak dan berperan penting dalam mengatasi kerusakan oleh radikal bebas. Vitamin C juga merupakan antioksidan kuat, tetapi vitamin ini larut dalam air. Kedua vitamin ini efektif dalam mengatasi radikal bebas. ${ }^{8}$

Beberapa penelitian menyebutkan bahwa vitamin $\mathrm{C}$ dan vitamin $\mathrm{E}$ dapat memperbaiki kualitas spermatozoa. ${ }^{9,10}$ Salah satu penelitian mengatakan bahwa pemberian vitamin $\mathrm{C}$ dapat menetralisir ROS dan mencegah kerusakan DNA yang disebabkan oleh ROS. ${ }^{11}$ Penelitian yang lain membuktikan bahwa vitamin E dapat mengurangi kerusakan sel spermatozoa yang disebabkan oleh ROS. ${ }^{12}$

Berdasarkan latar belakang diatas, penulis tertarik untuk melakukan penelitian tentang perbedaan antara efek pemberian vitamin C dan vitamin E terhadap kualitas spermatozoa tikus wistar jantan setelah diberi paparan asap rokok.

\section{METODE PENELITIAN}

Penelitian ini merupakan penelitian eksperimental dengan menggunakan rancangan acak lengkap. Penelitian dilakukan di laboratorium Biologi Fakultas Kedokteran Universitas Sam Ratulangi, dengan rentang waktu bulan November 2014 sampai dengan Desember 2014.

Bahan yang digunakan dalam penelitian ini adalah bahan makanan dan minuman untuk tikus, rokok kretek, vitamin C tablet, akuades, vitamin E kapsul, alkohol 30\% untuk melarutkan vitamin $\mathrm{E}$, bahan pemeriksaan kualitas sperma $(\mathrm{NaCl}$ fisiologis $0,9 \%$, methanol, larutan safranin, larutan kristal violet) dan hewan coba berupa tikus wistar jantan yang memenuhi kriteria inklusi, yaitu tikus wistar jantan berusia 5-6 bulan, berat badan 150-200 gram dan sehat, tingkah laku dan aktivitas 
tikus normal. Alat yang digunakan adalah kandang pemeliharaan, kandang perlakuan, pompa yang dimodifikasi untuk memompa rokok, sonde oral, bilik hitung hemasitometer Improved Neubauer, dissecting kit, objek gelas, gelas penutup, pipet tetes, cawan petri, mikroskop listrik, kamera digital dan timbangan digital.

Sampel penelitian ini berjumlah 15 ekor tikus wistar jantan (Rattus norvegicus) dibagi acak menjadi 3 kelompok, yaitu kelompok kontrol $\left(\mathrm{P}_{0}\right)$ hanya dengan paparan asap rokok 2 batang rokok/hari/5 tikus tanpa pemberian vitamin $\mathrm{C}$ dan vitamin E, kelompok perlakuan I $\left(\mathrm{P}_{1}\right)$ pemaparan asap rokok 2 batang rokok/hari/5 tikus dengan pemberian vitamin C 1,8 mg/hari dan kelompok perlakuan II $\left(\mathrm{P}_{2}\right)$ pemaparan asap rokok 2 batang rokok/hari/5 tikus dengan pemberian vitamin E 1,44 mg/hari.

Perlakuan dengan paparan asap rokok dilakukan setelah hewan coba mengalami aklimatisasi selama satu minggu. Setiap perlakuan pemaparan asap rokok dilakukan dalam kandang perlakuan. Bagian ujung rokok yang dibakar dimasukkan ke dalam kandang perlakuan. Jika rokok telah habis terbakar, hewan coba dikeluarkan. Setelah itu diberikan vitamin $\mathrm{C}$ yang telah dicairkan oleh akuades dan vitamin $\mathrm{E}$ yang telah dilarutkan dalam alkohol 30\% yang akan dimasukkan melalui sonde oral. Pemberian perlakuan dilakukan selama 52 hari.

Pada hari ke-53, hewan coba diterminasi menggunakan disecting kit untuk mengambil cauda epididimis. Selanjutnya cauda epididimis dimasukkan ke dalam cawan petri dan ditetesi NaCL 0,9\% sebanyak 5 tetes. Suspensi sperma dari cauda epididimis ini yang digunakan untuk pengamatan kualitas spermatozoa hewan coba meliputi konsentrasi spermatozoa, motilitas spermatozoa dan morfologi spermatozoa.

\section{HASIL PENELITIAN Konsentrasi spermatozoa}

Tabel 1. Hasil Perhitungan Rata-rata Konsentrasi Spermatozoa Tikus Wistar Jantan (Rattus norvegicus) Kelompok Kontrol dan Perlakuan

\begin{tabular}{cc}
\hline Kelompok & $\begin{array}{c}\text { Rata-rata konsentrasi } \\
\text { spermatozoa(10 } / \mathbf{m l})\end{array}$ \\
\hline Kontrol & 34,91 \\
P1 & 78,78 \\
P2 & 123,13 \\
\hline
\end{tabular}

Berdasarkan Tabel 1 , dapat dilihat bahwa kelompok kontrol dengan perlakuan paparan asap rokok sebanyak 2 batang/hari memiliki rata-rata konsentrasi spermatozoa sebesar 34,91. Kelompok $\mathrm{P}_{1}$ dengan perlakuan paparan asap rokok 2 batang/hari dan vitamin $C$ 1,8 $\mathrm{mg} /$ hari memiliki ratarata konsentrasi spermatozoa sebesar 78,78. Kelompok $\mathrm{P}_{2}$ dengan perlakuan paparan asap rokok 2 batang/hari dan vitamin $\mathrm{E}$ 1,44 mg/hari memiliki rata-rata konsentrasi spermatozoa sebesar 123,13. Menurut Blandau \& Odor, konsentrasi spermatozoa tikus wistar jantan (Rattus norvegicus) adalah $58\left(\times 10^{6} / \mathrm{ml}\right) .^{13}$

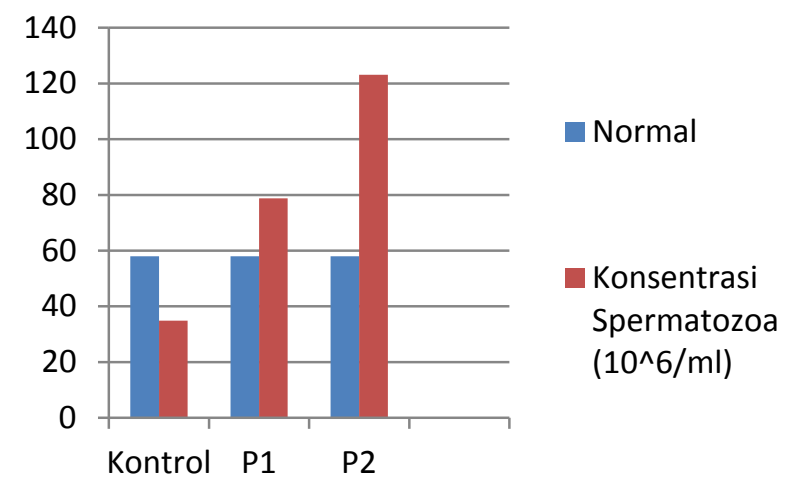

Gambar 1. Diagram Rata-rata Konsentrasi Spermatozoa $\left(10^{6} / \mathrm{ml}\right)$ Tikus Wistar Jantan (Rattus norvegicus) Kelompok Kontrol dan Perlakuan terhadap Konsentrasi Spermatozoa Normal 
Sitohang, Wantouw, Queljoe: Perbedaan antara efek...

\section{Motilitas spermatozoa}

Tabel 2. Hasil Perhitungan Rata-rata Motilitas Spermatozoa Tikus Wistar Jantan (Rattus norvegicus) Kelompok Kontrol dan Perlakuan

\begin{tabular}{cc}
\hline Kelompok & $\begin{array}{c}\text { Rata-rata motilitas } \\
\text { PR+NP } \\
\text { spermatozoa (\%) }\end{array}$ \\
\hline Kontrol & 23,25 \\
P1 & 72,00 \\
P2 & 80,25 \\
\hline
\end{tabular}

Keterangan: PR (Progressive motility); NP (Nonprogressive motility)

Berdasarkan Tabel 2 , dapat dilihat bahwa kelompok kontrol dengan perlakuan paparan asap rokok sebanyak 2 batang/hari memiliki rata-rata motilitas spermatozoa sebesar 23,25. Kelompok $\mathrm{P}_{1}$ dengan perlakuan paparan asap rokok 2 batang/hari dan vitamin C 1,8 mg/hari memiliki ratarata motilitas spermatozoa sebesar 72,00. Kelompok $\mathrm{P}_{2}$ dengan perlakuan paparan asap rokok 2 batang/hari dan vitamin $\mathrm{E}$ $1,44 \mathrm{mg} /$ hari memiliki rata-rata motilitas spermatozoa sebesar 80,25, sedangkan motilitas normal menurut WHO 2010 adalah total motilitas PR $+\mathrm{NP} \geq 40 \%{ }^{14}$

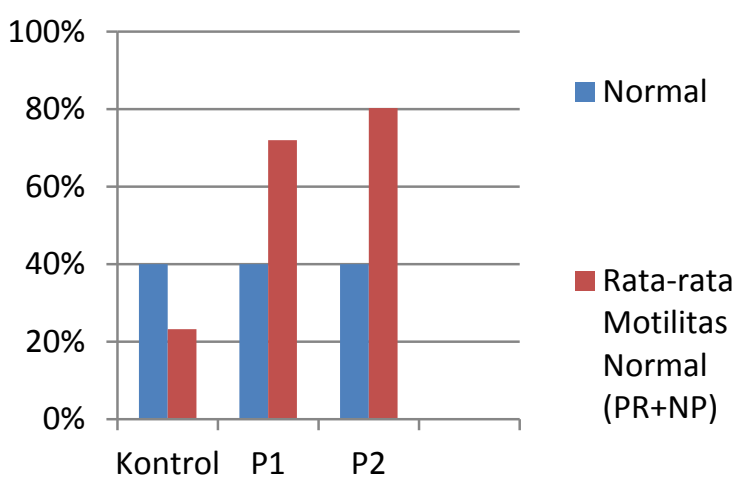

Gambar 2. Diagram Rata-rata Motilitas Spermatozoa (\%) Tikus Wistar Jantan (Rattus norvegicus) Kelompok Kontrol dan Perlakuan terhadap Motilitas Spermatozoa Normal Menurut WHO

\section{Morfologi spermatozoa}

Tabel 3. Hasil Perhitungan Rata-rata Morfologi Spermatozoa Tikus Wistar Jantan (Rattus norvegicus) Kelompok Kontrol dan Perlakuan

\begin{tabular}{ccc}
\hline \multirow{2}{*}{ Kelompok } & \multicolumn{2}{c}{$\begin{array}{c}\text { Rata-rata Morfologi } \\
\text { Spermatozoa (\%) }\end{array}$} \\
\cline { 2 - 3 } & Normal & Abnormal \\
\hline Kontrol & 44,75 & 55,25 \\
P1 & 67,63 & 32,37 \\
P2 & 74,00 & 26,00 \\
\hline
\end{tabular}

Morfologi normal dan abnormal dihitung dari 200 spermatozoa dari masingmasing sampel perlakuan. Berdasarkan Tabel 3 , dapat dilihat bahwa kelompok kontrol dengan perlakuan paparan asap rokok sebanyak 2 batang/hari memiliki rata-rata morfologi normal spermatozoa sebesar 44,75 dan morfologi abnormal sebesar 55,25. Kelompok $\mathrm{P}_{1}$ dengan perlakuan paparan asap rokok 2 batang/hari dan vitamin $C$ 1,8 mg/hari memiliki ratarata morfologi normal spermatozoa sebesar 67,63 dan morfologi abnormal sebesar 32,37. Kelompok $\mathrm{P}_{2}$ dengan perlakuan paparan asap rokok 2 batang/hari dan vitamin E 1,44 $\mathrm{mg} /$ hari memiliki rata-rata morfologi normal spermatozoa sebesar 74,00 dan morfologi abnormal sebesar 26,00 .

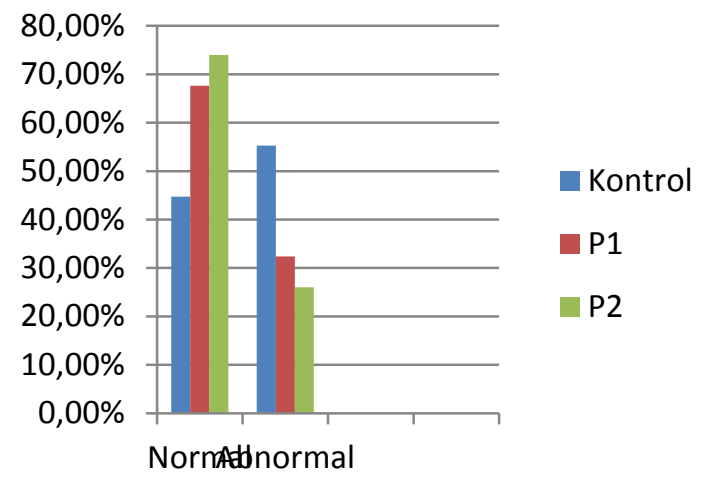

Gambar 3. Diagram Perbandingan Rata-rata Morfologi Normal dan Abnormal Spermatozoa (\%) Tikus Wistar Jantan (Rattus norvegicus) Kelompok Kontrol dan Perlakuan 


\section{BAHASAN}

Berdasarkan data penelitian pada Tabel 1 , dapat dilihat bahwa kelompok kontrol memiliki rata-rata konsentrasi spermatozoa sebesar 34,91( $\left.\times 10^{6} / \mathrm{ml}\right)$. Nilai konsentrasi spermatozoa tersebut kurang dari nilai konsentrasi spermatozoa tikus jantan normal menurut Blandau \& Odor yaitu $58\left(\mathrm{x} 10^{6} / \mathrm{ml}\right) .{ }^{13}$ Sedangkan kelompok $\mathrm{P}_{1}$ dan kelompok $\mathrm{P}_{2}$ memiliki peningkatan ratarata konsentrasi spermatozoa. Pada penelitian ini, kelompok $\mathrm{P}_{2} \quad(123,13$ $\mathrm{x} 10^{6} / \mathrm{ml}$ ) memiliki rata-rata konsentrasi spermatozoa lebih tinggi dibandingkan kelompok $\mathrm{P}_{1}\left(78,78 \times 10^{6} / \mathrm{ml}\right)$.

Menurut WHO 2010, motilitas normal jika total motilitas (Progressive motility + Non-progressive motility) $\geq 40 \%{ }^{14}$ Dari Tabel 2 dapat dilihat bahwa kelompok kontrol mengalami penurunan motilitas dengan persentase sebesar 23,25\%. Sedangkan kelompok $\mathrm{P}_{1}$ dan kelompok $\mathrm{P}_{2}$ mengalami peningkatan motilitas. Pada penelitian ini, kelompok $\mathrm{P}_{2} \quad(80,25 \%)$ mengalami peningkatan motilitas yang lebih tinggi dibandingkan kelompok $\mathrm{P}_{1}$ (72,00\%).

Dalam penelitian ini ditemukan perbedaan morfologi spermatozoa antara morfologi normal (bentuk kepala seperti kait dan ekor panjang lurus) dan abnormal (bentuk kepala terlalu bengkok, ekor tidak lurus, tidak berekor, dan ekor tanpa kepala). Pada Tabel 3, dapat dilihat bahwa kelompok kontrol memiliki persentase morfologi normal (44,75\%) lebih rendah dari morfologi abnormal (55,25\%). Sedangkan kelompok $\mathrm{P}_{1}$ dan kelompok $\mathrm{P}_{2}$ memiliki persentase morfologi normal (67,63\%; 74,00\%) lebih tinggi dari morfologi abnormal (32,37\%; 26,00\%). Pada penelitian ini, kelompok $\mathrm{P}_{2}$ memiliki persentase morfologi normal lebih tinggi dibandingkan kelompok $\mathrm{P}_{1}$.

Kelompok kontrol dengan perlakuan paparan asap rokok memiliki kualitas spermatozoa yang menurun dari normal. Rokok menyebabkan kadar peroksidasi lipid meningkat berkaitan dengan penurunan konsentrasi, motilitas, dan meningkatkan kelainan morfologi.
Spermatozoa kaya akan PUFA (Poly unsaturated fatty acids) yang sangat rentan terhadap serangan Reactive Oxygen Species. Hal ini dapat menyebabkan penurunan motilitas spermatozoa oleh karena kehilangan ATP intraselular yang menyebabkan kerusakan axonemal, peningkatan kelainan morfologi midpiece, efek merusak pada kapasitasi spermatozoa dan reaksi akrosom. Peroksidasi lipid juga menyebabkan kerusakan DNA dan protein. Produksi stres oksidatif mengakibatkan terjadinya fragmentasi DNA dalam sel spermatozoa \& kerusakan peroxidatif membran sel spermatozoa menyebabkan kematian sel dengan penurunan yang dihasilkan dalam jumlah spermatozoa. ${ }^{15}$

Hasil penelitian ini menunjukkan terjadinya peningkatan kualitas spermatozoa setelah pemberian vitamin $\mathrm{C}$ \& vitamin $\mathrm{E}$, hal ini sesuai dengan beberapa penelitian sebelumnya yang menyebutkan bahwa pemberian vitamin C dan vitamin $\mathrm{E}$ menunjukkan adanya peningkatan jumlah, motilitas, dan morfologi spermatozoa. ${ }^{10,16,17}$

Vitamin C merupakan vitamin larut air yang dapat melindungi spermatozoa dari kerusakan oleh stres oksidatif dengan cara menetralkan hidroksil, superoksida dan radikal hidrogen peroksida dan mencegah aglutinasi spermatozoa. Vitamin C mempunyai peran penting dalam melindungi lipid sperma yang mudah teroksidasi dari reaksi oksidasi yang akan menurunkan motilitas spermatozoa. ${ }^{18,19}$

Vitamin E merupakan antioksidan larut lemak dalam membran sel yang menghambat peroksidasi lipid dan meningkatkan aktivitas berbagai antioksidan yang dapat mengikat radikal bebas yang dihasilkan selama reduksi molekul oksigen dan selama aktivitas oksidatif enzim. Vitamin E dapat menurunkan kadar malondialdehyde pada spermatozoa, meningkatkan motilitas spermatozoa dan berperan dalam mengurangi fragmentasi DNA spermatozoa. ${ }^{18,20}$

Antioksidan yang paling efektif adalah vitamin E, dikarenakan vitamin E larut 
dalam lemak dan sangat penting karena sebagian besar kerusakan oleh radikal bebas terjadi pada membran sel dan lipoprotein berkepadatan rendah dan semua hal tersebut terbuat dari molekul lemak. Vitamin C juga merupakan antioksidan yang kuat, tetapi larut dalam air, bukan dalam lemak. ${ }^{8}$

\section{SIMPULAN}

Berdasarkan penelitian ini didapatkan bahwa terjadi perbedaan kualitas spermatozoa yaitu konsentrasi spermatozoa, motilitas spermatozoa dan morfologi spermatozoa pada kelompok dengan pemberian vitamin $\mathrm{C}$ dan kelompok dengan pemberian vitamin $\mathrm{E}$ setelah diberi paparan asap rokok. Pemberian vitamin E dapat memperbaiki kualitas spermatozoa setelah diberi paparan asap rokok dengan rata-rata kualitas spermatozoa lebih tinggi dari pemberian vitamin $C$ karena vitamin $\mathrm{E}$ larut dalam lemak dan sebagian besar kerusakan oleh radikal bebas terjadi pada molekul lemak.

\section{DAFTAR PUSTAKA}

1. Harahap MA. Hubungan karakteristik perokok, kadar CO dalam rumah dan perilaku merokok dengan kadar karboksihaemoglobin (HbCO) pada perokok aktif di lingkungan I kelurahan wek V kota Padang Sidempuan [tesis]. Universitas Sumatera Utara. 2013[citied 2014 Sep 16]. Available from:

http://repository.usu.ac.id/bitstream/12 3456789/38404/3/Chapter\%20II.pdf

2. Packer L, Fuchs J. Vitamin C in health and disease. New York: Marcel Dekker; 1997. p. 414.

3. Harris JE. Cigarette smoke components and disease: cigarette smoke is far more than a triad of tar,nicotine, and carbon monoxide. NCI smoking and tobacco control monographs 1996;7 (Chapt. 5): 59.

4. Karim D. Pengaruh paparan asap rokok elektrik terhadap motilitas, jumlah sel sperma dan kadar MDA testis mencit jantan (Mus musculus, L.) [tesis]. Universitas Sumatera Utara. 2011[citied 2014 Sep 14]. Available from:

http://repository.usu.ac.id/bitstream/12

3456789/26613/5/Chapter\%20I.pdf

5. Departemen Kesehatan. Masalah merokok di Indonesia.2010[citied 2014 Sep 14]. Available from: http://www.promkes.depkes.go.id/baha n/factsheet1cov.pdf

6. Suciati T. Pengaruh likopen terhadap gambaran tubulus seminiferus dan kualitas sperma mencit(muc musculus $L)$ yang terpapar asap rokok. Universitas sriwijaya Palembang. 2012[citied 2014 Sep 14]. Available from:

http://eprints.unsri.ac.id/4025/1/publika si_1.pdf

7. Quratul'ainy S. Pengaruh pemberian vitamin e terhadap jumlah spermatozoa mencit jantan strain balb/c yang diberi paparan asap rokok. Artikel kedokteran. Universitas Diponegoro Semarang. 2006[citied 2014 Sep 14]. Available from: http://eprints.undip.ac.id/20253/1/sari.p df

8. Youngson R. Antioksidan : manfaat vitamin C \& E bagi kesehatan. Jakarta: Arcan; 2005. p. 18-9.

9. Nugraheni T, Astirin OP, Widiyani $T$. Pengaruh vitamin c terhadap perbaikan spermatogenesis dan kualitas spermatozoa mencit (Mus musculus L.) setelah pemberian ekstrak tembakau (Nicotiana tabacum L.). Biofarmasi. 2003;1:13-9.

10.Christijanti W, Utami NR, Iswara A. Efek pemberian antioksidan vitamin c dan e terhadap kualitas spermatozoa tikus putih terpapar allethrin. Biosaintifika. 2010;2:18-26.

11.Kobori Y,Ota S, Sato R, Yagi H,Soh S,Arai G,et al. Antioxidant cosupplementation therapy with vitamin C,vitamin E, and coenzyme Q10 in patients with oligoasthenozoospermia. Archivio Italiano di Urologia e Andrologia. 2014;86:1-4.

12.Bansal AK,Bilaspuri GS. Antioxidant effect of vitamin $E$ on cattle spermatozoa. Animal Science Papers and Reports. 2009;27:5-14.

13.Kempinas WG, Lamano-Carvalho TL. A method for estimating the 
concentration of spermatozoa in the rat cauda epididymidis. Laboratory Animals. 1988;22:154-6.

14. World Health Organization. WHO laboratory manual for the examination and processing of human semen. 5th ed. Switzerland: WHO Press; 2010.p. 22-6.

15.Somwanshi SD, Madole MB, Bikkad MD,Bhavthankar SS, Gavkare A, Shelke B. Effect of cigarette smoking on sperm count and sperm motility. Journal of Medical Education \& Research. 2012;2:30-8.

16. Yulianto RA. Pengaruh vitamin e terhadap kualitas sperma tikus putih yang dipapar timbal. Skripsi fakultas MIPA Universitas Negeri Semarang. 2013[citied 2015 Jan 14]. Available from: http://lib.unnes.ac.id/19056/1/4450408 005.pdf

17. Claudia V. Perbedaan kualitas spermatozoa mencit jantan (mus musculus l) yang diberikan vitamin c setelah pemaparan asap rokok. eBM. 2013;1:629-34.

18.Agarwal A, Sekhon LH. The role of antioxidant therapy in the treatment of male infertility. Human Fertility. 2010; 13(4):217-25.

19.Fraga CG, Motchnik PA, Shigenaga MK, Helbock HJ, Jacobs RA, Ames BN. Ascorbic acid protects against endogenous oxidative DNA damage in human sperm. Medical Sciences.1991;88:11003-6.

20.Wen, C Joanne. The role of vitamin $E$ in the treatment of male infertility. Nutrition Bytes. 2006;11: 1-6. 